\title{
Knowledge Management of E-Government in Jordan
}

\author{
http://dx.doi.org/ijac.v4i4.1678 \\ Tamara Almarabeh \\ University of Jordan, Amman, Jordan
}

\begin{abstract}
Nowadays, knowledge management is considered an essential part of any organization to prepare and develop its vision for the future. Knowledge management allows better utilization of the organization expertise, resources, and bright ideas. The science of knowledge management started when the technology revolution reached every organization. The ease and availability of information, major advancements in communication technologies, the emergence of knowledge worker, and the knowledge economy are the reasons of knowledge management development.
\end{abstract}

Index Terms-E-government, Knowledge management, Jordan, MOICT.

\section{INTRODUCTION}

The world today is witnessing a massive wave of change multifaceted and objectives. The process of change and transition towards a knowledge society is a social process rather than economic process which associated with process of economic transition, industrial transition, and emergence of knowledge-based economics. This transformation process concluded to a global-wide change, such as emergence of the phenomenon of globalization, collapse of trade barriers and borders, and so on. According to these changes and developments, all institutions seeking to sustain their work, and survival in this changing world where this cannot be achieved unless the institution has a competitive advantage. The acquisition of correct knowledge which related to the work of the organization and management of such knowledge is the key factor in achieving competitive advantage. Unlike the traditional factors of production which became at secondary rank in the production process which we can copy them. Knowledge is the only resource that cannot be copied and it has a great value.

The old truism 'knowledge is power' has never been more true than it is today; knowledge is new currency of power [29]. Knowledge management which includes collecting updated right data, it provides the right information and capability of fast safe information delivery [20].

Jordan is part of this world. Jordanian institutions whether governmental or private institutions suffering today, from the pressures of global competition created by the wave of globalization in terms of liberalizing the movement of global trade, removal of border barriers to the movement of goods, services, and capital between different world countries. For example, the Jordanian government institutions suffer intense competition in attracting foreign investments at the region, which is required providing the best services to the Jordanian citizens and foreign investors alike.
Same applies to the private sector which producing goods and services are also facing other more kinds of competition in the domestic and global markets. This requires from the government and private sector institutions to have the ability to compete. These institutions will not reach to this stage unless they knowledge-based institutions and applying the knowledge management properly. No one can ignore the importance of knowledge which is an essential resource of the government and the performance of government rests significantly on the acquisition and use of resources [1].

Day after day, we can notice the importance of knowledge management for governments in their effort to deal with the growing challenges created by the knowledge economy.

This paper is organized as follows: in section II, defining e-government concept and explaining its importance. In section III, defining knowledge management concept and explaining its importance. In section IV, answering the question if there is relationship between e-government and knowledge management by introducing the reality of implementing knowledge management in Jordanian institutions with some problems. Finally the conclusion is drawn in section $\mathrm{V}$.

\section{DEFINITION AND IMPORTANCE OF E-GOVERNMENT}

To anyone who wants to understand the idea of Egovernment, must first understand government in general. Government is actually a dynamic mixture of objectives, structures and functions [2]. E-government is not governance per se, the essence of the concept is the " $E$ ", and that is, utilizing electronic E-government is more than a website, email or processing transactions via the internet. Egovernment becomes a natural extension of the technological revolution that has accompanied the knowledge society. The E-government added new concepts such as: transparency, citizen participation in the evaluation of government performance [4].

World Bank website provided definition of egovernment as:"...the use by government agencies of information technologies... that have the ability to transform relations with citizens, businesses, and other arms of government. These technologies can serve a variety of different ends: better delivery of government services to citizens, improved interactions with business and industry, citizen empowerment through access to information, or more efficient government management. The resulting benefits can be less corruption, increased transparency, greater convenience, revenue growth, and/or cost reductions..." [5]. 
According to the Institute for development Policy and Management [6], "e-government is the use of information and communication technologies (ICTs) to improve the activities of public sector organizations" and it covers: "Improving government processes: by bringing eadministration, making strategic connections in government, connecting citizens, building external interactions through e-society having good relationship between public agencies and other institutions”.

E-government can provide many benefits on the countries if they apply it correctly, it will make the government more transparent, efficient, and enable government information and services to be delivered to citizens in fast and easy manner with cost reduction [7]. The citizen does not need to go to different government offices when a mouse click at his/her home or other locations will do the same work in minutes [8].

Heeks [9] further explains that e-government providing 3 main benefits:

1. Improving government process / e-administration: by making processes time and cost effective, managing process performance, making strategic connections in government, and creating empowerment.

2. Connecting citizens: by providing citizens with public sector activities in details, increasing citizen input into government decisions and actions, and improving public services.

3. Building external interactions: by creating an esociety that involves improved relationships between public agencies and other public and private companies, interaction between government and business. E-government requires internet-based technologies to provide facilitated access to government information and services, and citizens and enterprises engagement through e-government portals as a collective vision of all government activities.

In Jordan, E-Government Program is a national initiative of his Majesty King Abdullah II, the mission is to manage change in the government and focus on the satisfaction of the recipients of government service, and achieving this through various channels to deliver the service using modern technology, knowledge management, recruitment experienced and qualified staff to implement e-government program and initiatives to be easy and acceptable to citizens in Jordan. The e-government program contributes effectively to develop and manage transformation of the government of Jordan.

To achieve this mission, the e-government program depends on applying the following themes:

- Applications related with the electronic services.

- Defining and developing appropriate technological infrastructure.

- Defining and developing the structure of adequate legislative and regulatory environment.

- Effective Process re-engineering to achieve high efficiency.

- Transformation and development in the field of education, training and knowledge transfer.

- Change management and restructuring of government institutions.

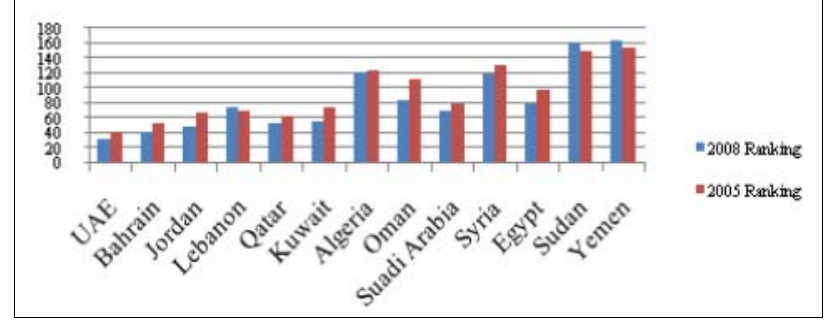

Figure 1. E-government Readiness (2005 and 2008 Rankings)

To achieve this, been assigned to Ministry of Communications and Information Technology (MOICT) working on the preparation of e-government strategy in coordination with various stakeholders. UN conducted a study [10] in 2008 presents a comparative assessment of 192 United Nations Member States'. According to this study, the provision of services has seen by government agencies significant development more than just being a traditional model of the government that provide services to citizens in traditional ways to focus heavily on E-government services to become one of the vital components that increase the value of services to citizens and then many countries in different regions of the world is reviewing strategies of developing public sector to ensure increased value of the services provided to the public through the electronic network and develop. The study showed readiness for egovernment that there is considerable variation between the five continents of the question of readiness for Egovernment For example, the Americas got 0.4936 points, Europe got 0.6490 points, Oceania by 0.4338 points, Asia 0.4470 points, and Africa is estimated at 0.2739 points. It should also be noted that Arab countries improved significantly since the 2005 survey, where Jordan moving up 18 positions as shown in Fig 1 . The reasons of this improvement return to understand the society for the importance of E-government, websites and services.

\section{DEFINITION AND IMPORTANCE OF KNOWLEDGE MANAGEMENT}

Knowledge Management (KM) has been defined differently by different authors. Prior studies defining knowledge management are shown in Table I.

For the purpose of this paper Misra's [19] approach is adopted, who defines Knowledge management for government as "leveraging Knowledge for improving internal processes, for formulation of sound government policies and programs and for efficient public service delivery for increased productivity”. This definition fits the context of this paper, because it is for the government and it is an inclusive definition.

The essence of knowledge management (KM) is to provide strategies to get the right knowledge to the right people at the right time and in the right format [26] in different applications as shown in Table II. Zhou \& Gao [30] have identified three benefits of knowledge management in e-government as being conducive to enhance governments' competence, to raise governments' service quality, and, to promote healthy development of egovernment.

King Abdullah II Award for Excellence for the public and private sectors came to be the main driver for improving the performance of the government and private Jordanian institutions, which particularly adopted knowledge management as one of the main criteria for this award. 
TABLE I.

KNOWLEDGE MANAGEMENT DEFINITIONS

\begin{tabular}{|c|c|}
\hline Author & Definition of knowledge management \\
\hline $\begin{array}{l}\text { Ouintas et al. } \\
\text { (1997) }\end{array}$ & $\begin{array}{l}\text { Knowledge management is to discover, develop, } \\
\text { utilize, deliver, and absorb knowledge inside and } \\
\text { outside the organization through an appropriate } \\
\text { management process to meet current and future } \\
\text { needs [11]. }\end{array}$ \\
\hline $\begin{array}{l}\text { Allee (1997) } \\
\text { Davenport (1998) } \\
\text { Alavi and } \\
\text { Leidner(2001) }\end{array}$ & $\begin{array}{l}\text { Knowledge management is managing the corpora- } \\
\text { tion's knowledge through a systematically and } \\
\text { organizationally specified process for acquiring, } \\
\text { organizing, sustaining, applying sharing and re- } \\
\text { newing both the tacit and explicit knowledge of } \\
\text { employees to enhance organizational performance } \\
\text { and create value [12] - 14] }\end{array}$ \\
\hline Gupta et al.(2000) & $\begin{array}{l}\text { Knowledge management is a process that helps } \\
\text { organizations find, select, organize, disseminate, } \\
\text { and transfer important information and expertise } \\
\text { necessary for activities [15] }\end{array}$ \\
\hline Bhatt(2001) & $\begin{array}{l}\text { Knowledge management is a process of knowl- } \\
\text { edge creation, validation, presentation, distribu- } \\
\text { tion and application [16] }\end{array}$ \\
\hline $\operatorname{Holm}(2001)$ & $\begin{array}{l}\text { Knowledge management is getting the right in- } \\
\text { formation to the right people at the right time, } \\
\text { helping people create knowledge and sharing and } \\
\text { acting on information [17] }\end{array}$ \\
\hline $\begin{array}{l}\text { Horwitch and } \\
\text { Armacost(2002) }\end{array}$ & $\begin{array}{l}\text { Knowledge management is the creation, extrac- } \\
\text { tion, transformation and storage of the correct } \\
\text { knowledge and information in order to design } \\
\text { better policy, modify action and deliver results } \\
\text { [18] }\end{array}$ \\
\hline
\end{tabular}

TABLE II.

REASONS TO ADOPT KNOWLEDGE MANAGEMENT

\begin{tabular}{|c|c|}
\hline Industry & $\begin{array}{c}\text { Reasons to adopt knowledge man- } \\
\text { agement }\end{array}$ \\
\hline Business Services & $\begin{array}{l}\text { Retain Expertise, Increase Customer } \\
\text { Retention }\end{array}$ \\
\hline Communications & Retain Expertise, Improve Profits \\
\hline Government & $\begin{array}{l}\text { Retain Expertise, Increase Customer } \\
\text { Retention }\end{array}$ \\
\hline Education & $\begin{array}{l}\text { Retain Expertise, Increase Customer } \\
\text { Retention }\end{array}$ \\
\hline Financial Services & Retain Expertise, Improve Profits \\
\hline $\begin{array}{l}\text { Discrete Manufactur- } \\
\text { ing }\end{array}$ & $\begin{array}{l}\text { Increase Customer Retention, Improve } \\
\text { Profits }\end{array}$ \\
\hline $\begin{array}{l}\text { Other Process Manu- } \\
\text { facturing }\end{array}$ & Retain Expertise, Improve Profits \\
\hline $\begin{array}{l}\text { Healthcare Services/ } \\
\text { Pharmaceuticals }\end{array}$ & $\begin{array}{l}\text { Retain Expertise, Increase Customer } \\
\text { Retention }\end{array}$ \\
\hline Insurance & $\begin{array}{l}\text { Increase Customer Retention, Improve } \\
\text { Profits }\end{array}$ \\
\hline Retail/Wholesale & $\begin{array}{l}\text { Retain Expertise, Increase Customer } \\
\text { Retention }\end{array}$ \\
\hline Transportation & $\begin{array}{l}\text { Retain Expertise, Increase Customer } \\
\text { Retention }\end{array}$ \\
\hline $\begin{array}{l}\text { Utilities/Energy/ } \\
\text { Chemicals }\end{array}$ & Retain Expertise, Improve Profits \\
\hline
\end{tabular}

\section{RELATIONSHIP BETWEEN E-GOVERNMENT AND KNOWLEDGE MANAGEMENT}

Nowadays, all levels of governments have either built or are building their own e-government systems to provide better service for the citizens at the same time to increase government efficiency. Similar to organizations in the private sector, which tend to regard knowledge management as simply building a corporate intranet or other IT systems, government people tend to regard e-government as the synonym of knowledge management. I would like to point out that these are two different concepts, the former emphasizing on the operation side while the latter emphasizing on the management side. It should also be noted that the proliferation and popularity of egovernment has laid out a solid foundation for the government to start their own knowledge management programs and to enjoy the benefits from these programs [3].

Misra [19] defines knowledge management for egovernment (KM4EG) as "management of knowledge for and by e-government for increased productivity. KM4EG is a management tool for government decision makers and its program implementers", and introduced 10 guiding principles for introduction of knowledge management in e-government shown in Table III.

TABLE III.

GUIDING PRINCIPLES FOR INTRODUCTION OF KNOWLEDGE MANAGEMENT IN E-GOVERNMENT

\begin{tabular}{|c|c|}
\hline $\begin{array}{l}\text { Guiding } \\
\text { Principle }\end{array}$ & Explain \\
\hline 1) & $\begin{array}{l}\text { Develop a knowledge management strategy for the } \\
\text { organization Leverage knowledge for achieving organ- } \\
\text { izational goals and serving citizens and non-citizens. }\end{array}$ \\
\hline 2) & $\begin{array}{l}\text { Proceed step-wise, from simple to the complicated. } \\
\text { Adopt modular approach. Do not attempt anything } \\
\text { highly ambitious in the initial stages. }\end{array}$ \\
\hline 3) & $\begin{array}{l}\text { Do not re-invent wheel. Make use of existing knowl- } \\
\text { edge and insights. Undertake knowledge needs assess- } \\
\text { ment. Only then plan the next step. }\end{array}$ \\
\hline 4) & $\begin{array}{l}\text { Make use of information and communication technolo- } \\
\text { gies (ICTs). But do not forget GIGO, garbage in, and } \\
\text { garbage out. }\end{array}$ \\
\hline 5) & $\begin{array}{l}\text { Make use of people, process and technology (PPT) } \\
\text { model. But do not forget: Computers: fast, accurate, } \\
\text { dumb, People: slow, sloppy, smart }\end{array}$ \\
\hline 6) & $\begin{array}{l}\text { Prepare a simple and modular knowledge sub-plan } \\
\text { incorporating knowledge management strategy. Do not } \\
\text { use any complicated knowledge management tool or } \\
\text { mechanism that cannot be successfully implemented. }\end{array}$ \\
\hline 7) & $\begin{array}{l}\text { Include knowledge management sub-plan in the e- } \\
\text { business plan of Ministry/Department. Do not prepare } \\
\text { any stand-alone knowledge management sub-plan. It is } \\
\text { more likely to fail than succeed. }\end{array}$ \\
\hline 8) & $\begin{array}{l}\text { Secure top management support to knowledge man- } \\
\text { agement sub-plan. Remember, no plan can succeed } \\
\text { without top management buy-in. This is to be a prior- } \\
\text { ity. }\end{array}$ \\
\hline 9) & $\begin{array}{l}\text { Demonstrate results. Remember, the best way to con- } \\
\text { vince anyone about practical utility of knowledge } \\
\text { Management is to show concrete, verifiable results. }\end{array}$ \\
\hline 10) & $\begin{array}{l}\text { Review the implementation of knowledge management } \\
\text { sub plan from time to time. }\end{array}$ \\
\hline
\end{tabular}


One of the main factors for the success of Egovernment requirements is the availability, accessibility, and applicability of appropriate governmental organizational knowledge within e-government systems [21]. Executives in government organizations recognize that in order to maintain or gain government competitive advantage, governmental knowledge needs to be managed and integrated into their e-government systems [22-24].

Knowledge management basing on the e-government environment is a new management concept, which has the potential to improve the provision of electronic services [25]. In the field of electronic service delivery, the knowledge management tools can add a lot of effectiveness on explaining the service, how to search for, access to, and can be characterizing the service as follows:

1. Find out why: Information on the nature of service, usefulness and purpose

2. Find out Whom: who will provide the service and who will get benefit?

3. Find out when: the date of service and the time required to obtain the result

4. Find out how: actions (procedures) related to the service

5. Find out where: site providing the service and receive the result

6. Find out what: the required documents and fees on the service.

Jain [28] introduced some recommendations to build a successful e-government:

- E-government should not be limited to a project level, but should be seen a comprehensive government wide ongoing process.

- There is a need of change management; individual change of mind-set and governmental change to keep pace with the global changes to gain and sustain a competitive edge;

- There should be strong collaboration at local, regional and national levels. Also between public and private sector organizations;

- Knowledge management portals should be based on citizen empowerment and interaction. They should provide multi-channels delivery of public services to cater for all levels of citizens and stakeholders.

- There is need for decision support systems to design new services tailored to citizen needs and suitable for a complex E-government scenario [31].

\section{A. The Reality of Implementing Knowledge Management in Jordanian Institutions}

Fortunately, the government and private institutions of Jordan began looking forward to be a knowledge-based institutions, especially since King Abdullah II Award for Excellence have adopted knowledge management as one of the standards of excellence. On this basis, the Jordanian institutions started both governmental and private in applying knowledge management initiatives. But we have to say honestly that these attempts are still in their infancy and they are far in their application to a large extent than the correct understanding and true knowledge management. For example, there is still considerable confusion between the concept of information and the concept of knowledge, confusion between the concept of technology management and the concept of knowledge management.
Anyone examines the knowledge management applications and contents of knowledge bases that are being built in our institutions generally, will find the management of knowledge that is applied is not the wanted, and the knowledge bases that are being built are the rules of data and information and not knowledge bases. A comparative analysis study between governmental institutions and private sectors used to determine the extent of using the Jordanian institutions for knowledge management. This study found that the degree of employment of knowledge management in Jordanian institutions in the public and private sectors is relatively limited. This is a clear indication of the vulnerability of the application of knowledge management in Jordanian institutions.

\section{B. Problems of Implementing Knowledge Management in Jordanian Institutions}

A number of problems, some old and some new, have arisen in knowledge management for and by egovernment in government, for example [27]:

- Information is not up to date.

- Required information is not available,

- Too much information is collected,

- Very little information is used in actual decisionmaking,

- There has been information explosion and

- New areas like information and communication technology (ICT), and e-government have emerged calling for collection of new information.

To address knowledge management problem in Jordan, it is necessary to examine the socio-cultural factors that affect on the development of knowledge management process in Jordanian organizations. Many of empirical researches on Arab management organizations indicate that organizations in these countries face many organizational and managerial problems, stemming from their bureaucratic designing and the culture power. Many scholars [32-36] denoted that Arab management practices are a mix of different characteristics: hierarchical authority, rules and regulations contingent on personality and power of individuals who make them, subordination of efficiency to personal relations and connections, indecisiveness in decision making, informality among lower level managers, a generally patriarchal approach and nepotism. Original thinking and creativity are condemned, and submissiveness and obedience are rewarded.

There are many reasons that hinder the application of knowledge management in Jordanian government and private institutions, the most prominent: Lack of awareness the fact that knowledge management is not management of information and management of technology held by the institution, but rather a management philosophy aimed at making the organization smarter and response to emergency situations and the changing environment. The knowledge management is used to make long-term improvements. There is no suitable support from senior management for the application of knowledge management because the lack of awareness for this fact. As a consequence there is no allocation of financial resources for the application of knowledge management, including correct training in the implementation. Here I would like to draw attention to the world attention for using knowledge management, as statistics indicate that investment in the field of knowledge management is a 
field of knowledge management is a successful investment worth 12.7 billion U.S. dollars in 2005.

There are several steps that can be done in order to become the Jordanian institutions of knowledge-based enterprises, including:

1. Establishment of governmental body dealing with matter of knowledge management, its job is public policy-making related to knowledge management initiatives launched in various public departments, implementation, and monitoring. Added to this, the body should provide advice and expertise to private sector.

2. Adding course in Jordanian universities enables students to understand the concept of knowledge management, benefits, objectives and operations, thereby enhancing their contribution in implementing knowledge management initiatives when they enter the labor market.

3. The organizations should involve their staff in training courses to enable them understanding the content of knowledge management.

4. Modifying the rewards and compensation systems to encourage the generating, transferring, sharing, and utilizing knowledge.

5. Need for concerned official bodies to encourage institutions, public and private - facilitating knowledge transfer and sharing, by opening channels of joint working between the public and private sectors with a view to strengthen relationships and partnerships between them. It would enhance the generation, transfer and sharing of knowledge.

6. Publishing the results of implementing the knowledge management initiatives in some public and private institutions, in order to broaden and strengthen the awareness of the benefits of knowledge management, so that these results become educated lessons and targets to follow.

\section{CONCLUSION}

This paper gives insight to the issues of knowledge management in e-government in general with a special emphasis on Jordan. It specifically investigated that the success of e-government depends on knowledge management. Knowledge management provides the overall strategy and techniques to manage e-government content. However, apparently there is need for better and more accurate understanding for knowledge management as an enabler for e-government to make knowledge more usable, accessible, and to keep it updated.

\section{REFERENCES}

[1] Misra D.C., Hariharan R., Khaneja M. (2003) E-Knowledge management framework for government organizations, Information systems management, Spring 2003, pp. 38-48. http://dx.doi.org/ 10.1201/1078/43204.20.2.20030301/41469.7

[2] Theresa A. Pardo, "Realizing the Promise of Digital Government: It's More than building a Web Site", Center of Technology in Government, University of Albany, 2000.

[3] Knowledge Management in Government Organizations and Programmes

[4] Hiba Mohammad, Tamara Almarabeh, and Amer Abu Ali, "Egovernment in Jordan”, European Journal of Scientific Research, Vol.35 No.2 (2009), pp.188-197.

[5] The World Bank Group 2009, Definition of E-Government, World Wide Web: http://www.worldbank.org/egov
[6] Institute for development Policy and Management. (2008), What is e-Government? World Wide Web: http://www.egov4dev.org/ success/definitions.shtml

[7] Danish Dada, "The Failure of E-government in Developing Countries: A Literature Review", The Electronic Journal on Information Systems in Developing Countries, Vol. 26 Issue 1 (2006), pp. 1 10.

[8] Jian Anna Xiong, "Current status and needs of Chinese egovernment users", Emerald Group Publishing Limited, The Electronic Library Vol. 24 No. 6, 2006, pp. 747-762.

[9] Heeks, R. (2008), What is E-Government? http://www.egov 4 dev.org/success/definitions.shtml

[10] UN E-government Survey 2008, "From E-government to Connected Governance".

[11] Ouintas, P., Lefrere, P. and Jones, G. (1997), "Knowledge management: a strategic agenda”, Long Range Planning, Vol. 30 No. 3, pp. 385-91. http://dx.doi.org/10.1016/S0024-6301(97)90252-1

[12] Alavi, M. and Leidner, D.E. (2001), "Review: knowledge management and knowledge management systems: conceptual foundations and research issues”, MIS Quarterly, Vol. 25 No. 1, pp. 10736. http://dx.doi.org/10.2307/3250961

[13] Allee, V. (1997), "Twelve principles of knowledge management”, Training\&Development, Vol. 51 No. 11, pp. 71-4.

[14] Davenport, T., De Long, D. and Beers, M. (1998), "Successful knowledge management projects”, Sloan Management Review, Vol. 39 No. 2, pp. 43-57.

[15] Gupta, B., Iyer, L.S. and Aronson, J.E. (2000), "Knowledge management: practices and challenges”, Industrial Management \& Data Systems, Vol. 100 No. 1, pp. 17-21. http://dx.doi.org/ $10.1108 / 02635570010273018$

[16] Bhatt, G. (2001), "Knowledge management in organizations: examining the interaction between technologies, techniques, and people”, Journal of Knowledge Management, Vol. 5 No. 1, pp. 6875. http://dx.doi.org/10.1108/13673270110384419

[17] Holm, J. (2001), "Capturing the spirit of knowledge management", paper presented at the American Conference on Information Systems, Boston, MA, August 3-5.

[18] Horwitch, M. and Armacost, R. (2002), "Helping knowledge management be all it can be", Journal of Business Strategy, Vol. 23 No. 3, pp. 26-32. http://dx.doi.org/10.1108/eb040247

[19] Misra, D.C. (2007), Ten Guiding Principles for knowledge Management in E-government in Developing Countries; World Wide Web http://unpan1.un.org/intradoc/groups/public/documents/UNP AN/UNPAN025338.pdf.

[20] Eanas Alsaffar, Lily Sun and Mohamed Magdy Kabeil, "EGovernments' Role Activation In Arab Countries", International Conference on Information Management and Engineering, 2009.

[21] Ping Zhou,, " A Strategy For Knowledge Management In EGovernment", isbim, vol. 1, pp.222-225, 2008 International Seminar on Business and Information Management, 2008

[22] Dion Hoe-Lian Goh, Alton Yeow-Kuan Chua,Brendan Luyt and Chei Sian Lee, "Knowledge access, creation and transfer in egovernment portals", Online Information Review, Vol. 32 No. 3 , 2008, pp.348- 369. http://dx.doi.org/10.1108/14684520810889664

[23] Copenhagen, Denmark, "Knowledge Management in eGovernment”, KMGov-2002, 3rd International Workshop on "Knowledge Management in e-Government", Schriftenreihe Informatik,Volume 7, pp.23 - 24, May 2002.

[24] Mario Tavares, Carlos J. Costa, "Knowledge Management Process in the Local Government”, SIGDOC’07, October 22-24, 2007, El Paso, Texas, USA., pp.182-188.

[25] Zhitian Zhou, Feipeng Gao, "E-government and Knowledge Management”, International Journal of Computer Science and Network Security, VOL.7 No.6, June 2007,pp.285-289.

[26] Milton, N., Shadbolt, N., Cottman, H. and Hammersley, M. (1999), "Towards a knowledge technology for knowledge management”, International Journal of Human-Computer Studies, Vol.51, pp.615-641. http://dx.doi.org/10.1006/ijhc.1999.0278

[27] First International Conference on Knowledge Management for Productivity and Competitiveness, January , 2007, New Delhi organized by National Productivity Council, http://www. npcindia.org/ 
PAPER

KNOWLEDGE MANAGEMENT OF E-GOVERNMENT IN JORDAN

[28] Priti Jain, "Knowledge Management In e-Government", Journal of Knowledge Management Practice, Vol. 10, No. 4, December 2009

[29] Chaudhary, Harish, 2005. Knowledge Management for Competitive Advantage. New Delhi: Excel Books.

[30] Zhou, Z., Gao, F. (2007), E-government and knowledge Management. IJCSNS International Journal of Computer Science and Network Security, 7(6), 285-289.

[31] Meo,P.D. (2008), A decision support system for designing new services tailored to citizen profiles in a complex and distributed egovernment scenario, Data \& knowledge Engineering, 67(1), 161184. http://dx.doi.org/10.1016/j.datak.2008.06.005

[32] Ali, A. and Sabri, H. (2001), "Organizational culture and job satisfaction in Jordan”, Journal of Transnational Management Development, Vol. 6 Nos 1/2, pp. 105-18. http://dx.doi.org/ 10.1300/J130v06n01 06

[33] Sabri, H. (1997), "The impact of national culture on organizational structure and culture”, PhD thesis (unpublished), Leeds University Business School, Leeds.
[34] Hickson, D. and Pugh, D.S. (1995), Management Worldwide: The Impact of Societal Culture on Organizations Around the Globe, Penguin Books, London.

[35] Attiyeh, H. (1993), "Roots of organization and management problems in Arab countries: cultural or otherwise?”, paper presented at the Arab Management Conference, July, Bradford Management Center, Bradford, pp. 6-8.

[36] Hofstede, G. (1997), Cultures and Organizations: Software of the Mind, McGraw-Hill, London.

\section{AUTHOR}

Tamara Almarabeh is with the Department of Computer Information Systems, The University of Jordan, Amman, CO 11942 Jordan (t.almaraabeh@ju.edu.jo).

Received 17 May 2011. Published as resubmitted by the author 15 October 2011. 